\title{
The Pandemic and Rhetoric of Organization
}

Arta Musaraj, Prof. Dr.

CEO, ETC - Entrepreneturship Training Center, Albania

\section{Abstract}

The need to understand, explain and define the traits and tools of the organization of our societies continuously brought to the creation of mechanisms such as merit and competence, structuration and stratification, spheres of right or colonization in the name of the civilization.

The final scope had been that of making them perceptible as observable rigid entities.

What happens when a virus and pandemic come to the stage of the global arena, which makes us act and operate at an individual level, as well as in all forms of organization we engage in, totally different from our expectations, motivations and communication of the day before it all started?

Are we living in the dawn of a new organism or is it just the confirmation that this had already started and now it is time to acquire and accept the new reality?

A new world and the need for new semantics, to reconceive the duality 'game' and 'play', in creating the new language, and hoping to come up with a new "generalized other" to guarantee us the future.

Keywords: pandemic; metaphor of organizing; crisis communication; play; game; knowledge management; globalism.

\section{Introduction}

9 years ago, Zigmunt Bauman in Rome ${ }^{12}$ referred to a slow-down communication, to the return to the Old World, made up of other ways, expressions and consumption.

The scent of a letter that took at least 2 days to arrive at the destination, if then after, the latest one was near enough.

In other words, to stop the frenzy of our new existence made of digits, which have elevated and embedded us in other spheres, certainly not those of the society, but those of our existence perceived as such. It seems we have found the genie in the bottle, the one to which we do not snap our fingers, but we use our fingers to type,

\footnotetext{
${ }^{1}$ www.internationalcommunicationsummit.com

${ }^{2}$ Musaraj, Arta. "History, sociology and politics: The strange triangles of Communication Day." Academicus International Scientific Journal 3.05 (2012): 12-16.
} 
and by doing so, we command, start and do things, the result of which is neither visible nor tangible, in most cases a bubble.

A somewhat visceral call to the last chance of human nature, intended as the result of a convergence after a long and nagging ontological abstraction on what it is and what is not.

In short, the last hope is to move from liquid to solid, from the oneiric construct and consumption of online feelings and affections, to the real one made of comparisons on what we are, rather than what we are able to give face to face.

In other words, this would mean moving on to being defined by consumption, built identities and communicated in them, that have now made us describable through prototypes and categories, consecrating the death of individuality.

\section{What's new in the World}

In an elementary exercise of Macroeconomics, a restriction of supply and demand occurs through a reduction in production and demand for consumption.

In short, the Coronavirus.

Born precisely in the largest production center in the World, China, transformed as if came true of the prophecy of the last national "guru" of this country, Mao Zedong, who had foreseen a world that would market what China would produce.

And although at first glance it seems that this production affects the consumption of most of the world's population, if not affecting the basic ones, it directly affects that part of consumption, goods and services that differentiate the welfare in most Western countries.

On the other hand, the quarantine in Western European countries, which in many cases, due to social models and cultural factors, could drop multiple times the consumption and demand for those services and consumables in an exponential model by directly affecting the liquid, the "too much", the excess, making us return to the necessary, more connected to our tangible than to the ideal.

So, a slow-down, the return to the Old Order, that made more of land and limits to consumption based on ephemeral feelings and concessions, reminding us that we are the same entities that use only $10 \%$ of their "processing" capacity ".

\section{The global organism and pandemic as an "organization" whiz}

The butterfly effect has given way to a series of writings on how much the globalized world has already acquired and put its rules on. 
There are those who produce and there are those who consume, and it is so since the beginning of the world as we know it, but in the great global village, those who produce and those who consume are distinguishable in geographies and races.

Two dimensions that the global village could not fail to inherit from the world before, indeed. But to the organization of our societies made up of stratification, spheres of right or mechanisms such as merit and competence, these definitions created by us to read our societies, the organizations within them, to make them perceptible as rigid entities, of a certain observable form, this new world calls to the need for all new semantics and to reconceive the duality 'game' and 'play' in creating the new language, and hoping to come up with a new "generalized other" to guarantee us the future.

Human beings can be considered and interpreted in their actions as caught in a continuous and desperate need to diminish the insecurities that come from the unknown. In the past, humanity has solved this problem by stereotyping and fueling racism.

But the global village often finds itself 'thanking' these traits of human behavior for being able to function as an entity: it needs input (food by analogy with the human body), a transformation system, and in its output it can not avoid having the excrements. And these traits are transformed into the mechanism that categorizes the components $^{3}$

In communicative terms this may be considered as a series of communicative iterations to externalize expectations, considerations and aims, processes which define the real nature of all forms of organizations.

By expanding the arena to that of today's interactions among countries, economies and social realities this means which role to play and which place to occupy in the global organism.

Human history tells of what choices we made to dealing with it: often by calling for the war which ends up all wars, since after everyone will occupy in the deserted place, playing a role, the one acquired or assigned from the confrontation.

By evolving, those who leaded and still wanted to do so, invented and started to apply the soft strategy of creating the alter ego, which in most of cases meant cultural assimilation of the weaker, and the main result was that of a pacific 'invasion' and claiming of roles and influences not necessary accepted and recognized by the many.

Pandemic in the era of international agreements and supra national governing bodies comes as the wiz which after closing everyone into its own shelter, first announces 
the new reality, that of telling what happened with nations, economies and countries which, by leveraging of the prejudice that had categorized them created a new identity which are now articulating.

Secondly, like the disciples of the "garbage can" theory for the problem-solution link in organization and society ${ }^{4}$ argue, in this globalized village, many learned and used the strategy of setting up a solution and find a stop in the road where to wait for the problem which their choices and those of others contributed to create.

To each solution its own problem, but the solution comes first.

Still one thing is certain: that the majority of the tribes are not in the part of the organism that elaborates. China, makes $28 \%$ of the the world overall production, half of which moved from other countries toward this destination thanks to the stereotype and cluster where they had inserted their inhabitants

\section{Communication to articulate a crisis or communication in times of crisis}

Now even the most unconscious have realized what is the real nature of this crisis.

The renewed definition of the word "crisis", taking on its primordial meaning, that of unknown and fear, seems to be the true physiognomy of it.

This is a vivid proof that the global communicative game must now be redone, since the organism has changed, mutated.

At the geo-political level, this means that all the strategies, stratagems and actions undertaken even in the most recent past, have become solutions for a problem that no longer exists in its past definition, therefore unpaired solutions to the problem are revealed.

The agreed division of the world has been skipped, and this is because agreements and roles of countries and nations have changed over time, and the dual culture and counter culture, as Ferrarotti suggests, in analyzing social dialectics and social conflict, ${ }^{5}$ has been played out in the birth of new communications that have given way to new roles, new understandings and consequently new structures.

The virus and the proclamation of the pandemic, in the modalities presented here and communicated to the world, take on the functions and dimensions that a "tomen" ${ }^{6}$ has

\footnotetext{
${ }^{4}$ Cohen, Michael D., James G. March, and Johan P. Olsen. "A garbage can model of organizational choice." Administrative science quarterly (1972): 1-25.

5 Ferrarotti, Franco. "Bismarck's Orphan: The Modern World and Its Destiny, from "Disenchantment" to the "Steel Cage"." Academicus International Scientific Journal 2.04 (2011): 11-34.

${ }^{6}$ Gandolfi, Enrico. "For a metaphorical tool to evoke identity: the tomen." Academicus International Scientific Journal 4.07 (2013): 44-53.
} 
in the metaphor for evoking identity, considering that in the new form of organization that is proposed, all members dispute to make use not of an identity ${ }^{7}$ that will be assigned as an unconditional consequence of the new communicative game, but trying to be incisive in the assignment of the new identity, through a violent play and game, fought trying to impose their own semantics, instead of agreeing on them.

According to ISPI "Bilateral Evaluation and Dispute Resolution Arrangement"

requires China to purchase $\$ 200$ billion more than the 2017 baseline at market prices for American goods in the 2020-21 two-year period. This is a particularly expensive prescription, the effective implementation of which is questioned by many for a list of rather specific products, and which would concern $\$ 77.7$ billion of manufacturing products, $\$ 32$ billion of agricultural products, $\$ 52.4$ billion of energy products and $\$$ 37.9 billion in services made in the USA.

But this agreement, like all commercial agreements in act, becomes void when "Pandemic" is proclaimed.

The series of communications to the health emergency, from where it began to the world, the unspoken truths, in order not to fall into the "politically incorrect" saying the misinformation in the form of demagogic press releases, are typical traits of a welltargeted communication strategy, and not a reference to a new "global conversation" to understand who is who, who will do what, through exploration, to compare themselves on the dialectics that have created new expectations of the countries for the role to play and place to occupy in the new body.

The analysis of communicative action ${ }^{9}$ and symbolic convergence ${ }^{10}$ at this point indicate a single word: Conflict as a unique solution to achieving expectations, a scenario that discards all alternative ones, which has become the only version of the future.

\section{Knowledge management as a metaphor of organizing}

The evolution of our organizations, of the forms of management of organizational complexity, have led to the creation of new definitions and real engines and means that have proven to be the new constants of organizational transformation.

Knowledge management is in fact the term that has become not only fashionable but a true management model in particular for organizations operating in fluid

\footnotetext{
${ }^{7}$ Marsonet, Michele. "National sovereignty vs. globalization." Academicus International Scientific Journal 8.15 (2017): $47-57$.

${ }^{8} \mathrm{https} / / /$ www.ispionline.it/it/pubbicazione/trade-deal-quali-conseguenze-usa-cina-ed-europa-24853

${ }^{9}$ Habermas, Jürgen. On the pragmatics of social interaction: Preliminary studies in the theory of communicative action. MIT Press, 2002.

${ }^{10}$ Bormann, Ernest G., John F. Cragan, and Donald C. Shields. "An expansion of the rhetorical vision component of the symbolic convergence theory: The Cold War paradigm case." Communications Monographs 63.1 (1996): 1-28.
} 
environments, of continuous change, and which consequently change significantly their definition and identity.

The capability of using the accumulated knowledge, particularly the set of capacities, attitudes and behaviors which support and accomplish all dialectics and the settle down, the fluid nature of all human interactions which compound all forms of organizations, at this point is being questioned.

If it is true that change becomes the real nature of all forms of organization ${ }^{11}$, it is also true that this process can be dramatically jeopardized under a managerial point of view since lacking references.

By deduction, the concept of the globalized world seems not only an outdated artifact but at the same time a demagogic tool with no corps, not of any mutual benefit and definitely, in no case anymore, an organizational mechanism in creating a common reality as a cooperation model.

The stunning situation questions both form and content.

It does not represent it in semantics, since those of the more recent past have lost their validity in giving way to action

"Never before has so much been known about what we do not know"

was what Habermass pointed out as the core characteristic and sentiment of today's societies and individuals in his interview of April 2020 released to the Financial Times ${ }^{12}$.

The fall of the mechanism which leaded to all convergences has brought down the very value of education systems based on knowledge management.

Education under this prospective, should be considered not what is being distributed through the classic education channels, but it refers to the need to articulate a value system-independently on the system- externalized and agreed upon, reference to the definition of what human society is today and what all forms of organization represent inside it.

A call to establish a moral system of management ${ }^{13}$, giving the latter the true mission of orienting companies, organizations and societies to swim, survive and redefine in uncertainty.

\footnotetext{
${ }^{11}$ Musaraj, Arta. "Communication processes, public administration and performance evaluation." Academicus International Scientific Journal 2.03 (2011): 28-37.

12 Habermass, J. Interview in Financial Times. April, 2020

${ }^{13}$ Musaraj, Arta. "Technocracy and the questionable moral philosophy of management. A Southeast Europe inside." Academicus International Scientific Journal 10.19 (2019): 37-48.
} 


\section{The "new" alteration and the lessons from the present}

The need to preserve the accumulated knowledge and transform it in a ready to use tool seemed to be fulfilled by the set of digits of $\mathrm{Al}$, which have been widely developed and customized particularly in the last years. The halo of a globalized culture, created the illusion that those tools were accessible to all with no any differentiation of origin ${ }^{14}$.

The basic principles were compliant with the transformation of the best experiences into behavioral models and technical means of solving problematic situations on the professional point of view.

However, their validity is being questioned in the new situation, since the old coupling between solution and problem does not exist anymore.

In the new situation these laces broke, giving that the definition of the problem, which always starts from a definition of the system, whatever it is, need to be re-invented but after and only after defining the identities of all forms of organization. And the latter will have to be defined in themselves.

The loose coupling is what Weick ${ }^{1516}$ considered a basic process. Probably that has already started years ago in the arena of global organization, by bringing change, the new situation and now everyone in the world must settle down by accepting and playing the new roles.

A plausible theory of social organization in a situation where convergence has been lost, and not only the symbolic one, but above all, that between communication and action understood as a model of organization and structuring.

Regardless of the model we refer to here, the emerging global body will be disputed for a long time, since countries lack more than just the agreements that flee from convergent symbols through which to communicate their expectations, roles to play and place to occupy in this mechanism.

The critical thing is that no organizational process on a global scale can not stand if this is not the result of evolutions in the systems and organizations inside them, such as to offer a communication model with accepted rules.

It will not happen as far as we assist into the birth of the new "generalized other" from the new "play" and "game".

\footnotetext{
${ }^{14}$ Marsonet, Michele. "National identity and global culture." Academicus International Scientific Journal 1.01 (2010): $44-48$.

${ }^{15}$ Weick, K. (2009), Making Sense of the Organization (Vol 2) The Impermanent Organization. Blackwell

${ }^{16}$ Weick, Karl E., Kathleen M. Sutcliffe, and David Obstfeld. "Organizing and the process of sensemaking." Organization science 16.4 (2005): 409-421.
} 


\section{Bibliography}

1. Bormann, Ernest G., John F. Cragan, and Donald C. Shields. "An expansion of the rhetorical vision component of the symbolic convergence theory: The Cold War paradigm case." Communications Monographs 63.1 (1996): 1-28.

2. Boyer, Marcel. Competition, Open Social Democracy, and the COVID-19 Pandemic. No. 2020pe-15. CIRANO, 2020.

3. Cox, Michael, Peter Watkins, and Linda Y. Yueh. "Does globalisation face an existential threat?." LSE COVID-19 Blog(2020).

4. Ferrarotti, Franco. "Bismarck's Orphan: The Modern World and Its Destiny, from "Disenchantment" to the "Steel Cage"." Academicus International Scientific Journal 2.04 (2011): 11-34.

5. Ferrarotti, Franco. "The Estrangement of Youth and the Quest for a different Society." Academicus International Scientific Journal8.16 (2017): 9-32.

6. Gandolfi, Enrico. "For a metaphorical tool to evoke identity: the tomen." Academicus International Scientific Journal 4.07 (2013): 44-53.

7. Habermas, Jürgen. "Moral universalism in times of political regression. Jürgen Habermas in conversation about the present and his life's work." (2020)

8. Habermas, Jürgen. On the pragmatics of social interaction: Preliminary studies in the theory of communicative action. MIT Press, 2002.

9. Habermass, J. Interview in Financial Times. April, 2020

10. Mead, G.H. (1934). Mind, Self, and Society. Ed. by Charles W. Morris. University of Chicago Press.

11. Marsonet, Michele. "National identity and global culture." Academicus International Scientific Journal 1.01 (2010): 44-48.

12. Marsonet, Michele. "National sovereignty vs. globalization." Academicus International Scientific Journal 8.15 (2017): 47-57.

13. Musaraj, Arta. "Communication processes, public administration and performance evaluation." Academicus International Scientific Journal 2.03 (2011): 28-37.

14. Musaraj, Arta. "History, sociology and politics: The strange triangles of Communication Day." Academicus International Scientific Journal 3.05 (2012): 12-16.

15. Musaraj, Arta. "Technocracy and the questionable moral philosophy of management. A Southeast Europe inside." Academicus International Scientific Journal 10.19 (2019): 37-48.

16. Sułkowski, Łukasz. "Covid-19 pandemic; recession, virtual revolution leading to de-globalization?." Journal of Intercultural Management 12.1 (2020): 1-11. 
17. Szeligowski, Sebastian Płóciennik Justyna Szczudlik Daniel, et al. "The Great Lockdown: Impact of the COVID-19 Pandemic on the Global Economy."

18. Thirlwell, Mark P. Return of Geo-economics: Globalisation and National Security. Lowy Institute for International Policy, 2010.

19. Weick, K. (2009), Making Sense of the Organization (Vol 2) The Impermanent Organization. Blackwell

20. Weick, Karl E., Kathleen M. Sutcliffe, and David Obstfeld. "Organizing and the process of sensemaking." Organization science 16.4 (2005): 409-421.

21. https://www.ispionline.it/it/pubbicazione/trade-deal-quali-conseguenze-usacina-ed-europa-24853

22. www.internationalcommunicationsummit.com 